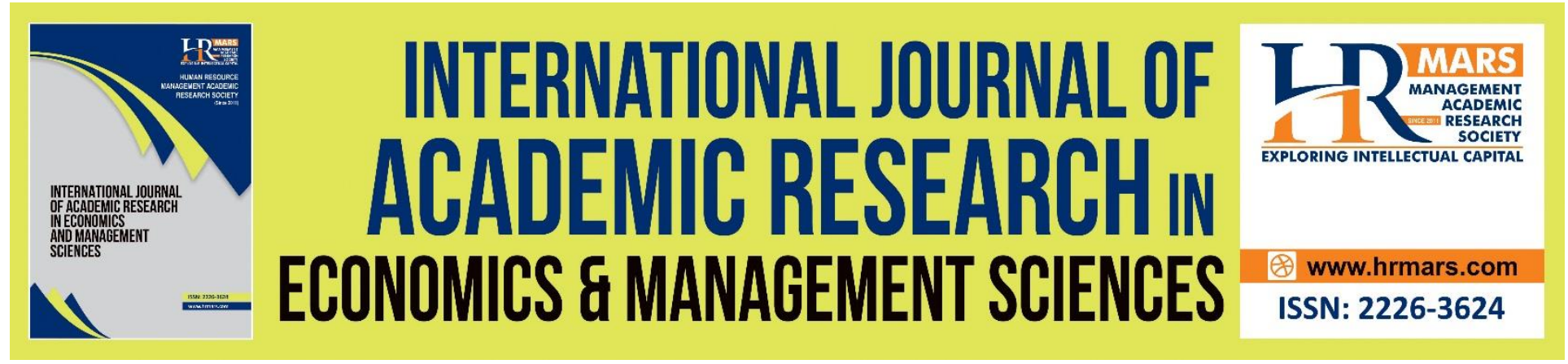

\title{
Knowledge Management Capabilities and Hotel Performance in Malaysia: The Role of Market Orientation
}

\author{
Nor Shahrul Muhamad Nor, Syed Jamal Syed Mohamad and Amily Fikry \\ To Link this Article: http://dx.doi.org/10.6007/IJAREMS/v10-i3/10769 $\quad$ DOI:10.6007/IJAREMS/v10-i3/10769
}

Received: 08 June 2021, Revised: 30 June 2021, Accepted: 15 July 2021

Published Online: 28 August 2021

In-Text Citation: (Mohamad \& Fikry, 2021)

To Cite this Article: Mohamad, N. S. M. N. S. J. S., \& Fikry, A. (2021). Knowledge Management Capabilities and Hotel Performance in Malaysia: The Role of Market Orientation. International Journal of Academic Research in Economics and Management and Sciences, 10(3), 168-182.

Copyright: (C) 2021 The Author(s)

Published by Human Resource Management Academic Research Society (www.hrmars.com)

This article is published under the Creative Commons Attribution (CC BY 4.0) license. Anyone may reproduce, distribute, translate and create derivative works of this article (for both commercial and non-commercial purposes), subject to full attribution to the original publication and authors. The full terms of this license may be seen at: http://creativecommons.org/licences/by/4.0/legalcode

Vol. 10, No. 3, 2021, Pg. 168 - 182

http://hrmars.com/index.php/pages/detail/IJAREMS

JOURNAL HOMEPAGE

Full Terms \& Conditions of access and use can be found at http://hrmars.com/index.php/pages/detail/publication-ethics 


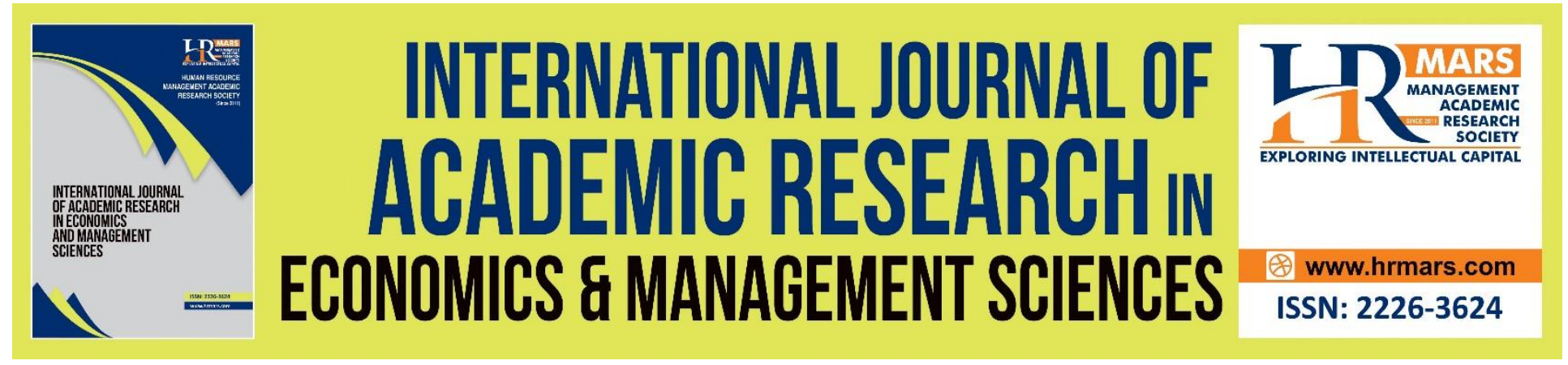

\title{
Knowledge Management Capabilities and Hotel Performance in Malaysia: The Role of Market Orientation
}

\section{Nor Shahrul Muhamad Nor ${ }^{1}$, Syed Jamal Syed Mohamad ${ }^{2}$ and Amily Fikry ${ }^{3}$}

${ }^{1}$ Department of Postgraduate and Professional Studies, Faculty of Business and Management, Universiti Teknologi MARA, 40000 Shah Alam, Selangor, Malaysia, ${ }^{2}$ Arsyad Ayub Graduate Business School (AAGBS), Universiti Teknologi MARA, 40000 Shah Alam, Selangor, Malaysia,

${ }^{3}$ Faculty of Business and Management, Universiti Teknologi MARA, 42300 Puncak Alam, Malaysia.

Email: norshahrulnizam76@gmail.com, syedjamal145@uitm.edu.my,amily@uitm.edu.my, amily@uitm.edu.my

\begin{abstract}
This study is concerned with the impact of Knowledge Management Capabilities (KMC) and Market Orientation (MO) on Hotel Performance (HP) in Malaysia. The World Tourism Organization (2018) highlighted that the global tourism industry today attracts around 1.245 billion international tourists, with trillions of US dollars expected to be generated from tourism in 2016. The tourism industry, which includes hoteliers, must follow the current market trends to ensure that its performance is sustainable in a competitive environment. Therefore, hoteliers must provide sufficient knowledge to their employees in terms of infrastructure and process to deal with market trends. However, many of them are still reluctant to embrace management adaptation. The data for this study were collected from the top management of 146 hotels. Top management in this context included managers, managing directors, or chief operating officers from three-star to five-star hotels in Malaysia. The results show that knowledge management capabilities have a significant relationship with market orientation. The findings suggest that market orientation strengthens the relationship between knowledge infrastructure and hotel performance. The paper presents a few contributions. Firstly, the framework can be a support tool for top management in the hotel industry to develop knowledge management capabilities that cater to the market in sustaining competitiveness. Secondly, the research broadens the scope of opportunities for future research.
\end{abstract}

Keywords: Knowledge Management Capabilities, Market Orientation, Hotel Performance, Tourism 


\section{Introduction}

Tourism contributes substantial gross domestic product (GDP) to many countries in the world based on data from the World Bank, which shows that the total number of international tourist arrivals was at around 555 million in 1995, and increased to 1.245 billion in 2016. Meanwhile in Malaysia, the tourism industry contributed 7.5 million international tourists and 26.8 million in 1995 and 2016 respectively (World Tourism Organization, 2018). However, due to the Covid-19 pandemic, the number of international tourists visiting Malaysia decreased by $83.4 \%$ to only 4.33 million in the year 2020, which contributed around RM12.7 billion to the country (Malaysian Tourism Ministry, 2021). Weidenfeld (2006) found that the tourism industry is already a saturated market, and new segmentations have emerged such as eco, religious, nature, and so forth. Furthermore, in the hotel industry, hoteliers tend to focus on specific markets known as 'specialised niche markets' such as Shariah compliance, boutique, and businesswomen hotels (Nor et al., 2012). It is due to the tourism and hospitality industry that the world has changed from being product-focused to customer-focused to cater to the tourist trends and demands (Bharwani \& Mathews, 2016).

Based on the market trends and emerging market, knowledge is a must for all companies in the tourism and hospitality industry, including hotels and how these players react towards their customers and tourists' demands (Nor et al., 2019; Nor et al., 2012; Poloski-Vokic, 2008). To cater to the changes and success in the business, the companies must provide knowledge to all their staff (Poloski-Vokic, 2008). Furthermore, Zahari et al (2013) agreed that the $21^{\text {st }}$ century is the era of knowledge and people at work are able to manage it effectively as part of companies' survival and sustainability. From a macro perspective, Albassam (2019) mentioned that countries must have an effective knowledge management system to maintain sustainability and be part of the inclusive development of such organisation. A country's economy needs the learning knowledge to develop rapidly, resulting in an impact on the market orientation of the organization to become more competitive (Hamzah et al., 2020). Furthermore, Guimaraes et al. (2017) stressed that organizations must identify and develop strategies to achieve sustainable competitive advantages over competitors.

\section{Problem Statement}

World business landscapes change rapidly due to consumers' trends and preferences, which have lead to the emergence of new market segmentation (Weidenfeld, 2006). Ngah et al (2016) urged the changes in business landscape, especially in the services industry, to adopt and practise knowledge management so as to sustain in a competitive environment. Furthermore, Albassam (2019) suggested that countries must have an effective knowledge management system in the perspective of developed nations to sustain their competitiveness. Therefore, it is high time for companies to practise knowledge management and acquire intellectual resources in the industry (Alavi et al., 2005). Meanwhile, Payal, Ahmed and Debnath (2016) agreed that the service industry requires knowledge management for modern business survival. Therefore, the absence of knowledge, skills and capabilities at the appropriate levels might slow down the organizations' competitiveness (Khan, 2019). However, small and medium size companies (herein after refers to SMEs) which have limited resources but face changes in the market situation, commonly react accordingly with their existing knowledge, resources and capabilities (Randhawa et al, 2020). 
Worse still, organizations face difficulties in implementing and maintaining effective knowledge programs from time to time (Gold et al., 2001).

The tourism and hospitality industry has already reached a saturated level and need to be shifted into new market (Nor et al., 2019). This can happen with knowledge management in the industry so it can react accordingly towards its customers and guests' demands (Poloski-Vokic, 2008). Furthermore, Stephenson et al. (2010) found that knowledgeable and skilled managerial people will contribute to excellent performance and business success, particularly in the hotel and tourism industry. Moreover, employees are one of the successful factors and part of the essential assets for companies (Poloski-Vokic, 2008). Tavitiyaman et al. (2012) found that skilled employees assist in the betterment of their hotel management. Sheresheva (2016) reiterated that skilled employees must be balanced with the development in tourism and hospitality industry, initiated by developing countries to compete with developed countries. The latter have excellent and superior services to attract more potential and repeating guests to stay at their hotels.

However, Cooper (2006) highlighted that due to the unstable environment, tourism industry players are reluctant to adopt knowledge management. This is supported by Abdullah and Ahmad (2010), who found that Malaysian hoteliers are obviously aware of Islamic regulations due to the demand by the majority of hotel guests as well as the country's stature as an Islamic country. Unfortunately, they are still lacking in terms of Syariah compliance and practices. Therefore, Tavitiyaman et al. (2012) stressed that hoteliers must provide their employees with the knowledge to polish their skills and use information technology to improve their performance.

\section{Literature Review}

\section{Knowledge Management Capabilities}

Knowledge is one of the most significant assets and is consider as a form of wealth to organizations to become superior business performers and sustain competitive advantage (Barney, 1991; Grover \& Davenport, 2001). Bolisani and Bratianu (2018) defined knowledge as an abstract concept transformed into the tangible world. Meanwhile, Anjari (2020) defined knowledge management as a set of methods, tools, and techniques for managing processes in companies. Steward and Waddel (2008) added that knowledge management has been developed for more than four decades, and was implemented in organizations at the beginning; in academic and practical disciplines, it has been in place since the late $20^{\text {th }}$ century. Al-Hawari (2004) presented a different perspective, where knowledge management was defined as an object which might be codified, understood, disseminated, and applied in order to achieve the companies' goals. Meanwhile, Chiu and Chen (2016) defined knowledge management capabilities as a continuous mechanism and intentionally meant to create knowledge in the organization. Alavi and Leidner (2001) defined it as capability to create, transfer, integrate, and apply the knowledge.

It involves a radical transformation or overhaul in an organization starting from assumptions, structures, as well as value systems to recast and rebuild these to become a knowledge 
organization. Hindasah and Nuryakin (2020) highlighted that organizations must continuously support knowledge management in the organization to improve performance. Therefore, the organization must develop capabilities and recognize them as opportunities for knowledge integration. Zhang et al. (2018) divide knowledge management capabilities into three types; technological, structural, and cultural. However, Lee and Yang (2000), and Gold et al. (2001) have a different view of knowledge management, where they divide it into two categories, mainly knowledge infrastructure and knowledge process.

Knowledge infrastructure or company assets according to Wu and Chen (2014), is defined as infrastructure of companies to build up the systems and services in supporting the core business. Previously, Lee and Yang (2000) noted that a company's infrastructure is a combination of structure, technology, and culture in the company. Meanwhile, Gil-Padilla and Espino-Rodriguez (2008) elaborated that technology infrastructure has become one of the company's resources and culture that affect hotel performance in the industry. Gold et al (2001) highlighted that social capital for infrastructure capability in an organization can be maximized through three dimensions; structural, cultural, and technological. Mohannak (2011) found that culture as a part of knowledge infrastructure has significant evidence of importance to an organization's knowledge management success or failure. Gold et al. (2001) found that there is a direct and significant relationship between knowledge infrastructure and organizational effectiveness. Thus, as depicted in Figure 1, the following hypothesis is examined:

H1a: There is a direct relationship between knowledge infrastructure and hotel performance.

To leverage the infrastructure, an organization needs a knowledge process in which knowledge is efficiently captured, stored, reconciled and disseminated (Nonaka \& Takeuchi, 1995). The knowledge process is the company's ability to generate knowledge and make it as its competitive advantage. Su and Lin (2006) defined the knowledge process to identify business core competencies and the related knowledge categories, demands and requirements needed to identify business core competencies. It consists of knowledge generation, dissemination, and application (Lee \& Yang, 2000). Meanwhile, Wu and Chen (2014) divide knowledge process into the creation process, transfer process, integration process, and application process as an integration process for an organization to nurture the knowledge. Gold et al (2001) found that knowledge process capability consists of knowledge acquisition, conversion, application, and protection. Therefore, Gold et al. (2001) found that there is a direct and significant relationship between the knowledge process with organizational effectiveness. Thus, the following hypothesis is examined:

$\mathrm{H} 1 \mathrm{~b}$ : There is a direct relationship between knowledge process and hotel performance.

\section{Market Orientation}

Market orientation is known as companies' characteristics in continuous understanding and responding to the customers as well as their competitors. Barney (1991) describes market orientation as one part of organizational capabilities which relate to the competencies of companies such as resources and capabilities that give them having competitive superiority compared to their competitors. Meanwhile, Qodriah et al. (2021) described market orientation 
as a pillar of superiority of strategy orientation affecting organizational performance. Samat et al. (2006) highlighted that market orientation focuses on customers, which is very important to the business. Lestari et al (2020) agreed that market orientation is a commitment to continuous creativity in generating superior value to customers' needs due to global competition. Therefore, Ramayah et al (2011) found that market orientation is a very important element for organizations in facing global competition. Hamzah et al. (2020) highlighted that the economy in developing countries is changing rapidly, thus affecting market orientation in those countries. Organizations therefore need to focus on being competitive.

However, Lukas and Farrel (2000) as well as Slater and Narver (1995) described that market orientation affects companies' focus on their customers and competitors and at the same time neglects new knowledge or other perspectives. Interestingly, Randhawa et al. (2020) found differences in the perspectives of companies, especially the way SMEs react towards changes in market conditions and have limited resources. They tend to utilise their existing knowledge, resources and capabilities to sustain competitiveness. Therefore, market orientation has become one of the core capabilities of companies (Lukas \& Farrel, 2000). Sheresheva (2016) agreed that market orientation has also become one of the main factors for tourism and hospitality industry's development. Au and Tse (1995) mentioned that the tourism and hospitality industry must be aware of market orientation which can lead to its successful performance in the service industry. However, Takata (2016) noted that market orientation not only affects the service industry, but also becomes a vital factor affecting manufacturers' performance.

Gotteland et al (2020) proposed that strategic orientation, which consists of market and technology orientation, stimulates companies' performance. Previously, Narver and Slater (1990) divided market orientation into customer orientation, competitor orientation and interfunctional coordination that positively associate with performance. Meanwhile, Slater and Narver (1995) found that the combination of market orientation and entrepreneurship leads to learning orientation, which finally affects companies' performance. Narver et al. (2004) agreed that market orientation and innovation orientation positively affect a new product's success. However, Hilman and Kaliappen (2014) stated that market orientation is based on two perspectives: competitor and customer orientations.

Competitor orientation, which is one part of market orientation, has been defined as companies' culture for short term specialties, long term abilities, and tactics against main rivals (Hilman \& Kaliappen, 2014; Narver \& Slater, 1990). Another part of market orientation is competitor orientation that urges companies to develop a holistic strategy based on their evaluation towards their rivals. Meanwhile, customer orientation is a part of companies' culture which refers to the needs and wants from their present or potential customers (Narver \& Slater, 1990).

A lot of research has found a direct relationship between market orientation and performance. Market orientation as the mediator in the relationship between two variables has also been positively shown in many researches. Martelo et al. (2013) found that market orientation significantly intervened between knowledge management and customer relationship management in financial industry. Hamzah et al. (2020) also significantly mediate between two 
variables; learning orientation and job performance. Thus, the following hypotheses are examined (refer Figure 1):

$\mathrm{H} 2 \mathrm{a}$ : Market orientation positively mediates the relationship between knowledge infrastructure and hotel performance.

$\mathrm{H} 2 \mathrm{~b}$ : Market orientation positively mediates the relationship between knowledge process and hotel performance.

\section{Hotel Performance}

Performance is generally viewed as an individual or organization's degree of understanding (Le \& Nguyen, 2020). Meanwhile, Organizational performance is a business goal outcome that is set up by that organization (Narver \& Slater, 1990; Narver et al, 2004; Salim \& Rajut, 2021; Slater \& Narver, 1995). Hoi and Ngui (2014), and Gill-Padilla and Espino-Rodriguez (2008) found that organizational performance is derived from organization resources such as human resources and technology infrastructure, as well as organizational capabilities. Furthermore, Gotteland et al. (2020) agreed that strategic orientation such as market orientation and technology orientation lead companies' performance. Lestari et al. (2020) mentioned that performance of organizations must be built on business strategies, knowledge-sharing capabilities, entrepreneurship abilities, innovation as well as market orientation. Meanwhile, in the tourism and hospitality industry, there are a few studies on employees that influence their performance, such as Karatepe and Uludag (2008).

Companies' performance according to most researches comprises two perspectives: financial performance (Kim, 2008) and non-financial performance (Gil-Padilla \& Espino-Rodriguez, 2008). However, Ramayah et al (2011) found that most researches on performance are based on three factors; financial performance, organizational effectiveness, and business performance. Basically, companies' performance is based on Resource-Based Value or RBV theory (Barney, 1991). From the perspectives of tourism and hospitality, researches on hotel performance normally focused on management (Kim, 2008), environment (Cortez et al., 2007) and marketing aspects (Jang, Hu \& Bai, 2006). Alonso-Almeida et al. (2016) measured both perspectives, namely financial and non-financial on hotel industry growth performance during two crises in Europe.

Meanwhile, Tavitiyaman et al (2012) studied competitive strategies by focusing on non-financial and financial perspectives of hotel performance. Previously, Philips (1999) agreed that competitive strategies such as the process starting from input, output, environmental characteristics, and market and strategic orientation could affect the measurement of hotel performance from both perspectives. Meanwhile, Gil-Padilla and Espono-Rodriguez (2008) found that resources and capabilities influence hoteliers' performance. Furthermore, Tajeddini (2009) supported that learning orientation (part of organizational capabilities) positively affects hotel performance. Therefore, studies on hotel performance specifically focusing on non-financial performance still need to be explored. This is in line with Sainaghi et al (2013), who found that many researches on hotel performance were based on quantitative measurements with a picture 
of profitability in terms of its efficiency. They also suggested looking for more on qualitative measure to redefine hotel strategies in future research.

Furthermore, Wu and Chen (2014) suggested that most of research of knowledge management and business performance must reflect the actual performance. Therefore, Payal et al. (2016) found a positive relationship between knowledge management and organizational performance which focus on human factors (non-financial performance). This is supported by Ramayah et al. (2011), who found in their research on market orientation that organizations tend to cover effectiveness.

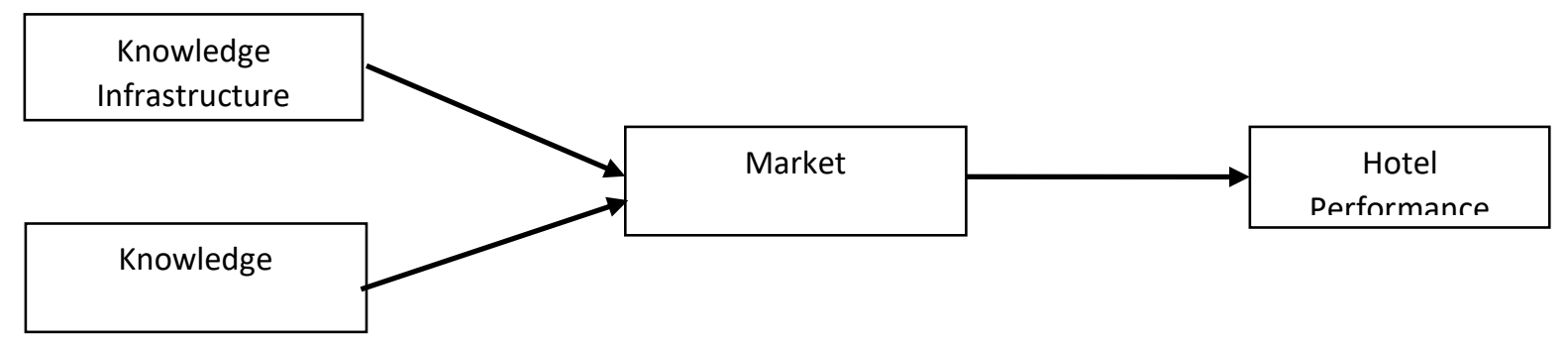

Figure 1: The framework

\section{Methodology}

This research used the quantitative method and was conducted by e-survey. Respondents were initially selected randomly among top management from 266 hotels in Malaysia. Top management included managers, director-managers, or owners of the hotels. Respondents were well-versed on the implementation of knowledge management and market orientation for their hotels. The chosen hotels were three-star to five-star in terms of services and equipment provided to the guests and based on the list from Ministry of Tourism comprising 863 hotels under these categories. However, due to the lack of response, the method of distribution changed from simple random to purposive sampling. The data collected was analysed by the Statistical Package for the Social Science (SPSS) Equation Model, which provides a comprehensive understanding of multidimensional nature of Market Orientation (Pallant, 2016) and Partial Least Squares Structural Equation Modeling (PLS-SEM) for the size, direction, and significance of the structural parameter estimates (Hair et al., 2016).

The scales used were 7-point Likert-type scale with $1=$ strongly disagree and $7=$ strongly agree. The questions developed for knowledge management capabilities were adopted from Gold et al. (2001). Meanwhile, the constructs for market orientation were taken from Gray et al. (1998), Narver and Slater (1990), as well as Slater and Narver (1996). Hotel performance constructs were based on the non-financial performance scale from Narver and Slater (1990).

\section{Findings}

According to Pallant (2016), a reliability test is looking for internal consistency for the items scale being used for the research. One of the common indicators is Cronbach's Alpha, which is based on the average correlation of items within a test if the items are standardized and it ranges in value from 0 to 1 . It is a reliability coefficient that reflects how well the items in a set are positively correlated to one another. Meanwhile, Zikmund (2003) added if the result of the reliability 
statistic is less than 0.6, it is considered poor, and a range between 0.6 till 0.8 is considered as acceptable. Meanwhile, results over 0.8 are considered good. Therefore, for this test, the reliability test in Table 1 shows that all items were considered as very good and excellent.

Table 1: Reliability Test

\begin{tabular}{|c|c|c|c|}
\hline Variable & No of items & $\begin{array}{l}\text { Cronbach's } \\
\text { Alpha }\end{array}$ & Result \\
\hline $\begin{array}{c}\text { Knowldge } \\
\text { Infrastucture }\end{array}$ & 16 & 0.882 & Very good \\
\hline $\begin{array}{c}\text {-Organizational } \\
\text { culture }\end{array}$ & 12 & 0.880 & Very good \\
\hline -Structure & 12 & 0.891 & Very good \\
\hline -Technology & & & \\
\hline $\begin{array}{l}\text { Knowlege } \\
\text { Process }\end{array}$ & 12 & 0.872 & Very good \\
\hline -Acquisition & 10 & 0.913 & Excellent \\
\hline -Conversion & 13 & 0.943 & Excellent \\
\hline -Application & 19 & 0.959 & Excellent \\
\hline Market Orientation & 5 & 0.915 & Excellent \\
\hline Hotel performance & & & \\
\hline
\end{tabular}

Meanwhile for the ANOVA test, the $P$ value for each variable shows significant results, which is less than 0.05 except for structures under knowledge structure as shown in the Table 2 below. It seems that, regardless of the structure built or prepared by hotel management for staff knowledge, it is not related to market orientation.

Table 2: ANOVA

\begin{tabular}{|l|l|l|}
\hline Variable & P Value & Result \\
\hline Knowldge Infrastucture: & & \\
\hline -Organizational culture & 0.018 & Significant \\
\hline -Structure & 0.156 & Not significant \\
\hline -Technology & 0.028 & Significant \\
\hline Knowlege Process & & \\
\hline -Acquisition & 0.024 & Significant \\
\hline -Conversion & 0.003 & Significant \\
\hline -Application & 0.001 & Significant \\
\hline
\end{tabular}

\section{Mediation}

A mediator variable occurs when it intervenes between other related constructs. In this study, market orientation shows relationships to mediate between knowledge management and hotel performance (as shown in Table 3). However, mediating effects for the relationship between knowledge infrastructure and hotel management is still not significant. Meanwhile, 
INTERNATIONAL JOURNAL OF ACADEMIC RESEARCH ECONOMICS AND MANAGEMENT SCIENCES

Vol. 10 , No. 3, 2020, E-ISSN: 2226-3624 @ 2020 HRMARS

with mediation, the result shows lower $\mathrm{P}$ value compared with direct relationship between these two variables.

Table 3: Mediating Analysis

\begin{tabular}{|l|c|c|c|c|c|}
\hline \multicolumn{1}{|c|}{ Variables } & $\begin{array}{l}\text { Original Sample } \\
\text { (O) }\end{array}$ & $\begin{array}{l}\text { Sample } \\
\text { Mean (M) }\end{array}$ & $\begin{array}{l}\text { Standard } \\
\text { Deviation } \\
\text { (STDEV) }\end{array}$ & $\begin{array}{l}\text { T Statistics } \\
\text { ([O/STDEV } \\
\text { ]) }\end{array}$ & P Values \\
\hline $\begin{array}{c}\text { Knowledge } \\
\text { Infra -> Hotel } \\
\text { Performance }\end{array}$ & 0.230 & 0.231 & 0.120 & 1.922 & 0.055 \\
\hline $\begin{array}{l}\text { Knowledge } \\
\text { Process -> Hotel } \\
\text { Performance }\end{array}$ & 0.603 & 0.597 & 0.150 & 4.024 & 0.000 \\
\hline $\begin{array}{l}\text { Knowledge } \\
\text { Infra-> Market } \\
\text { Orientation-> } \\
\text { Hotel Performance }\end{array}$ & 0.185 & 0.200 & 0.092 & 2.011 & 0.045 \\
\hline $\begin{array}{l}\text { Knowledge } \\
\text { Process-> Market } \\
\text { Orientation-> } \\
\text { Hotel Performance }\end{array}$ & 0.366 & 0.368 & 0.084 & 4.354 & 0.000 \\
\hline
\end{tabular}

\section{Hypotheses Testing}

The research hypotheses results were based on the formula from Structural Equation Modelling (SEM). The mixed results appear for these four hypotheses. There is a positive and significant relationship between knowledge processes and hotel performance. Meanwhile, the relationship between knowledge infrastructures and hotel performance shows different results, with no relationship between these two variables. The same scenario applies to market orientation as mediator, whereby it is not significant between knowledge infrastructure and hotel performance. For the last hypothesis, which is to test the relationship between the knowledge process and hotel management and mediated by market orientation, the results shown were positive.

\section{Conclusion}

There are mixed results for the relationship between knowledge management capabilities and market orientation as well as market orientation and hotel performance. However, the mediating test shows differently. Market orientation positively mediates between knowledge process and hotel performance. Another scenario is where the results for market orientation as mediator is not supported between the relationships of knowledge infrastructure and hotel performance. It proves that the knowledge process is still important to hotels specifically and the service industry in general to keep them up-to-date with the current market and trends to ensure they can perform better. Hoteliers must provide an adequate knowledge process to their employees and ensure their staffs are at ease to generate, disseminate, and apply the knowledge provided for them. Once they are well-equipped with knowledge, management and staff will be ready to serve 
their guests confidently with the latest information and market trends, as well as compete with other competitors fairly.

According to the results, knowledge infrastructure such as latest technologies, and structure in the hotel might not be so important in entertaining their guests. For them, as long as they have been provided with knowledge regardless of not updating the organization's knowledge infrastructure, the management and their staff can still enjoy their services and contribute to the hotel performance.

However, there were some limitations of this research. Firstly, the research involved three to five-star hotels only. Therefore, it does not represent the whole hotel industry. Second, the sample was taken from one country, Malaysia, and over a particular period of time. Another limitation was from the data collection method used, which was purposive sampling. Initially, this sampling was chosen to collect the data due to slow responses from the target respondents at the initial stage, where simple random was chosen. This method of sampling could therefore be biased to the results as shown above.

Therefore, for future research, firstly another perspective, either in knowledge management or market orientation needs to be developed. Secondly, hotel performance can be measured by two perspectives, namely financial and non-financial performances to ensure more solid research. Another point to ponder is research focus on the types of hotels, which can give more reliable results compared to general hotel operators.

\section{Contributions}

In the hotel industry, financial perspectives is usually being used to measure hotel performance. Also, past research in the area of knowledge management capabilities and organizational effectiveness do not focus on market orientation. Therefore, this research fill in the gaps by measuring hotel performance using non-financial perspectives. Additionally, this research also add on market orientation as a mediator. The positive result of mediating effects will certainly add knowledge and contribute to the future research as well.

In practical perspectives, hotel managers of three-star to five-star hotels in Malaysia may apply the result of this research to improve the measurement of their hotel performance. For example, in measuring their hotel performance, hotel managers need to look into hotel's characteristics (i.e. market orientation). Besides of that, hotel managers usually measure hotel performance using financial performance only. Now, based on this research, hotel managers may consider to measure their hotel performance based on both financial and non-financial measurement approaches.

\section{References}

Alavi, M., Kayworth, T. R., \& Leidner, D. O. (2005). An Empirical Examination of the Influence of the Organizational Culture on Knowledge Management Practice. Journal of Management Information Systems, 22(3), 191-224.

Alavi, M., \& Leidner, D. O. (2001). Review; Knowledge Management and Knowledge Management Systems; Conceptual Foundations and Research Issues. MIS Q, 25(1), 107-136. 
Albassam, B. A. (2019). Building an Effective Knowledge Management System in Saudi Arabia Using the Principle of Good Governance. Resources Policy, 64, 1-8.

Anjaria, K. (2020). Negation and Entropy: Effectual Knowledge Management Equipment for Learning Organizations. Expert Systems with Applications, 1-15.

Ansari, F. (2019). Knowledge management 4.0: Theoretical and Practical Considerations in Cyber Physical Production Systems. International Federation of Automatic Control, 52(13), 15971602.

Au, A. K., \& Tse, A. C. (1995). The Effect of Marketing Orientation on Company Performance in the Service Sector: A Comparative Study of the Hotel Industry in Hong Kong and New Zealand. Journal of International Consumer Marketing, 8(2), 77-87.

Barney, J. (1991). Firm Resources and Sustained Competitive Advantage. Journal of Management, 17(1), 99-120.

Bharwani, S., \& Matthews, D. (2016). Customer Service Innovations in the Indian Hospitality Industry. Worldwide Hospitality and Tourism Themes, 8(4), $415-431$.

Bolisani, E., \& Bratianu, C. (2018). The Elusive Definition of Knowledge. Emergent Knowledge Strategies, 1-22.

Chiu, C. N., \& Chen, H. H. (2016). The Study of Knowledge Management Capabilities and Organizational Effectiveness in Taiwanese Public Utility: The Mediator Role of Organizational Commitment. SpringerPlus 5, 1520. https://doi.org/10.1186/s40064-016-3173-6

Cooper, C. (2006). Knowledge Management and Tourism. Annals of Tourism Research, 33(1), 4764.

Fazey, I. R. A., Proust, K., Newell, B., Johnson, B., \& Fazey, J. (2006). Eliciting the Implicit Knowledge and Perceptions of On-Ground Conversation Managers of the Macquarie Marshes. Ecology and Society, 11(1), 25-53.

Gill-Padilla, A. M., \& Espino-Rodriguez, T. F. (2008). Strategic Value and Resources and Capabilities of Information Systems Area and their Impact on Organization Performance in the Hotel Sector. Tourism Review, 63 (3), 21-47.

Gold, A. H., Malhotra, A., \& Segars, A. H. (2001). Knowledge Management: An Organizational Capabilities Perspective. Journal of Management Information Systems, 18(1),185- 214.

Gotteland, D., Shock, J., \& Sarin, S. (2020). Strategic Orientation, Marketing Proactivity and Firm Market Performance. Industrial Marketing Management, 1-11.

Gray, B., Matear, S., Boshoff, C., \& Matheson, P. (1998). Developing a Better Measure of Market Orientation. Journal of Service Marketing, 32(9/10), 884-903.

Grover, V., \& Davenport, T. (2001). General Perspectives on Knowledge Management: Fostering a Research Agenda. Journal of Information System, 18(1), 5-21

Guimaraes, J. S. F., Severo, E. A., \& Vasconcelos, C. R. M. (2017). The Influence of Entrepreneurial, Market, Knowledge Management Orientation on Cleaner Production and Sustainable Competitive Advantage. Journal of Cleaner Production, 1653-1663.

Hair, J. F., Hult, G. T. M., Ringle, C. M., \& Sarsted, M. (2016). A Primer on Partial Least Squares Structural Equation Modeling (PLS-SEM). SAGE Publications.

Hamzah, M. I., Othman, A. K., \& Hassan, F. (2020). Mediating Effects of Individual Market Orientation and Job Performance. Journal of Business \& Industrial Marketing, 35(4), 655668 
Hilman, H., \& Kaliappen, N. (2014). Market Orientation Practices and Effects on Organizational Performance: Empirical Insight from Malaysia Hotel Industry. Sage and Open Access Page, 1-8.

Hindasah, L., \& Nuryakin, N. (2020). The Relationship between Organizational Capability, Organizational Learning and Financial Performance. Journal of Asian Finance Economics and Business, 7(8), 625-633.

Hooi, L. W., \& Ngui, K. S. (2014). Enhancing Organizational Performance of Malaysian SMEs: The Role of HRM and Organizational Capability. International Journal of Manpower, 35(7), 973995.

Jennex, M. E., \& Olfman, L. (2004). Assessing Knowledge Management Success. International Journal of Knowledge Management, 2(3), 33-49.

Khan, M. H. (2019). Knowledge, Skills and Organizational Capabilities for Structural Transformation, Structural Change and Economic Dynamics, 48, 42-52.

Lee, C. C., \& Yang, J. (2000). Knowledge Value Chain. Journal of Management Development, 19(9), 783-794.

Le, T. N., \& Nguyen, D. D. (2020). An Impact of Budgetary Goal Characteristics on Performance: The Case Study of Vietnamese SMEs. Journal of Asian Finance Economics and Business, 7(9), 363-370.

Lestari, S. D., Leon, F. M., Widyastuti, S., Brabo, N. A., \& Putra, A. H. P. K. (2020). Antecedents and Consequences of Innovation and Business Strategy on Performance and Competitive Advantage of SMEs. Journal of Asian Finance Economics and Business, 7(6), 365-378.

Lukas, B. A., \& Ferrel, O. C. (2000). The Effect of Market Orientation on Product Innovation. Journal of the Academy of Marketing Science, 28(2), 239-247

Malhotra, N. K. (2004). Review of Marketing Research. Prentice Hall.

Marshall, L. (1997). Facilitating Knowledge Management and Knowledge Sharing: New Opportunities Information Professionals. Online, 21(5), 92-98.

Martelo, S., Barosso, C., \& Cepeda, G. (2013). The Use of Organizational Capabilities to Increase Customer Value. Journal of Business Research, 66, 2042-2050

Ministry of Tourism Malaysia (2021). Malaysian Statistic in Brief. https://www.tourism.gov.my/statistics

Ministry of Tourism Malaysia. (2017). Tourism associations under Malaysian Association of Hotels. http://www.tourism.gov.my/industry/view/tourism-associations

Mohannak, K. (2011). Diversity in Managing Knowledge: A Cultural Approach, Economic Research Centre Discussion Paper 1-34. http://eprints.qut.edu.au

Zahari, M. A. S., Ab Rahman, B., Othman, A. K., \& Wahab, S. (2013). Investigating the Relationship between Customer Knowledge Management and Knowledge Sharing among Insurance Companies in Malaysia. Asian Social Science, 9 (10), 60-70.

Narver, J. C., \& Slater, S. F. (1990). The Effect of Market Orientation on Business Profitability. Journal of Marketing, 20-35.

Narver, J. C., Slater, S. F., \& MacLachlan, D. L. (2004). Responsive and Proactive Market Orientation and New-Product Success. The Journal of Product Innovation Management, 21, 334-347. 
Ngah, R., Tai, T., \& Bontis, N. (2016). Knowledge Management Capabilities and Organizational Performance in Roads and Transport Authority of Dubai: The Mediating Role of Learning Organization. Knowledge and Process Management, 23(3), 184-193.

Nonako, I., \& Takeuchi, H. (1995). The Knowledge-Creating Company: How Japanese Companies Create the Dynamics of Innovation. New York.

Nor, N. S. M., Syed, S. J. M., \& Fikry, A. (2019). Is Market Orientation influenced by Knowledge Management Capabilities?: A Pilot Study among Hoteliers in Malaysia. International Tourism and Hospitality Journal, 2(3), 1-6.

Nor, N., Mohd-Nor, N., \& Mohd-Nor, A. (2012). Challenges facing woman entrepreneurs in the hospitality and tourism Malaysia (Paper presentation). World Islamic Economic Forum (WIEF 2012), Kuala Lumpur.

Pallant, J. (2016). SPSS; Survival Manual: $6^{\text {th }}$ Edition. Mc Graw Hill Education.

Payal, R., Ahmed, S., \& Debnath, R. M. (2016). Knowledge Management and Organizational Performance: A Study in the Context of Indian Software Companies. The IUP Journal of Knowledge Management, 14(4), 53-71.

Pentland, B. T. (1995). Information System and Organizational Learning: The Social Epistomology of Organizational Knowledge Systems. Accounting, Management and Information Technologies, 5(1), 1-21.

Poloski-Vokic, N. (2008). The Importance of Educated and Knowledgeable Employees for the Hotel Industry Performance: The Case of Croatia (Paper presentation). The $4^{\text {th }}$ International Conference 'An Enterprise Odyssey: Tourism-Governance and Entrepreneurship', Hrvatska, Zagreb.

Qodriah, S. L., Darsono, D., Riani, A. L., \& Anantanyu, S. (2021). Strategy Orientation, Innovation Capability, and Women Entrepreneurial Performance in Culinary Business in Indonesia. Journal of Asian Finance, Economics and Business, 8(7), 0203-0213.

Ramayah, T., Samat, N., \& Lo, M.C. (2011). Market Orientation, Service Quality and Organizational Performance in Service Organizations in Malaysia, Asia-Pacific Journal of Business Administration, 3, 8-27.

Randhawa, K., Wilden, R., \& Gudergan, S. (2020). How to Innovate toward an Ambidextrous Business Model? The Role of Dynamic Capabilities and Market Orientation. Journal of Business Research, 1-17.

Sainaghi, R., Philips, P., \& Corti, V. (2013). Measuring Hotel Performance; Using a Balanced Score Card Perspective's Approach. International Journal of Hospitality Management, 34(1), 150159.

Salim, A., \& Rajput, N. A. R. (2021). The Relationship between Transformational Leadership, Prosocial Behavioral Intentions, and Organizational Performance. Journal of Asian Finance, Economics and Business, 8(1), 487-493.

Samat, N., Ramayah, T., \& Saad, N. M. (2006). TQM Practices, Service Quality, and Market Orientation: Some Empirical Evidence from a Developing Country, Management Research News, 29, 713-728.

Sheresheva, M. (2016). Russian Hospitality and Tourism: What needs to be addressed?. Worlwide Hospitality and Tourism Themes, 8(3), 380- 396.

Slater, S. F., \& Narver, J. C. (1995). Market Orientation and the Learning Organization. Journal of Marketing, 59, 63-74. 
Stephenson, M. L., Russel, K. A., \& Edgar, D. (2010). Islamic Hospitality in the UAE: Indigenization of products and human capitals. Journal of Islamic Marketing, 1(1), 9 -24.

Tavitiyaman, P., Zhang, H. Q., \& Qu, H. (2012). The Effect on Competitive Strategies and Organizational Structure on Hotel Performance. International Journal of Contemporary Hospitality Management, 24(1), 140-159.

Wang, K. L., Chiang, C., \& Tung, C. M. (2012). Integrating Human Resources Management and Knowledge Management: From the Viewpoint of Core Employees and Organizational Performance. The International Journal of Organizational Innovation, 5(1), 109-137.

Weidenfeld, A. (2006). Religious needs in the hospitality industry. Tourism and Hospitality Research, 6(2), 143-159

World Tourism Organization. (2018). International Tourism; Number of Arrival 995-2016. World Bank. https;//data.worldbank.org/indictors/st.int.arvl

Wu, I. L., \& Chen, J. L. (2014). Knowledge Management Driven Firm Performance: The Roles of Business Process Capabilities and Organizational Learning. Journal of Knowledge Management, 18(6), 1141-1164.

Zhang, Y., Liu, S., Tan, J., Jian, G., \& Zhu, Q. (2018). Effects of Risks on the Performance of Business Process Outsourcing Projects: The Moderating Roles of Knowledge Management Capabilities. International Journal of Project Management, 36, 627-639

Zikmund, W. G. (2000). Business Research Methods ( $\left.6^{\text {th }} \mathrm{Ed}\right)$. The Dryden Press. The Dryden Press. 